220

Received: July 28, 2016

Accepted: March 31, 2016
Macedonian Journal of Animal Science, Vol. 6, No. 2, pp. 95-100 (2016)

In print: ISSN $1857-6907$

On line: ISSN $1857-7709$

UDC:597.551.2-111

Original scientific paper

\title{
COMPARATIVE PHYSIOLOGICAL ASSESSMENT OF COMMON CARP (CYPRINUS CARPIO) AND CRUCIAN CARP (CARASSIUS CARASSIUS) BASED ON ELECTROLYTE AND HEMATOLOGICAL ANALYSIS
}

\author{
Damir Suljević ${ }^{1}$, Andi Alijagić ${ }^{2}$, Maja Mitrašinović-Brulić ${ }^{1}$, Muhamed Fočak ${ }^{1}$, Erna Islamagić ${ }^{1}$ \\ ${ }^{1}$ Department of Biology, Faculty of Science, University of Sarajevo, \\ Zmaja od Bosne 33-35, 71000 Sarajevo, Bosnia and Herzegovina, \\ ${ }^{2}$ Trg solidarnosti 21/21, 71000 Sarajevo, Bosnia and Herzegovina, \\ andialijagic@gmail.com
}

\begin{abstract}
Studies based on biochemical and hematological parameters in fish are significant in monitoring of health and early detection of pathological conditions. This research obtained values of serum electrolytes and hematological parameters in crucian carp $(n=15)$ and common carp $(n=13)$. Significantly different values of $\mathrm{K}^{+}, \mathrm{Cl}^{-}$and $\mathrm{Ca}^{2+}$ concentration were detected. In serum of common carp there were significantly higher concentration of $\mathrm{K}^{+}$and $\mathrm{Cl}^{-}$and lower concentration of $\mathrm{Ca}^{2+}$, compared to the crucian carp. Hematological parameters differ in these two species. In blood of common carp significantly lower PCV, hemoglobin concentration, RBC and MCV and notably higher $\mathrm{MCHC}$ and WBC were obtained, compared to crucian carp. This preliminary research is important in establishing referential range of biochemical and hematological parameters in cyprinid fishes.
\end{abstract}

Key words: common carp; crucian carp, electrolytes; hematological parameters; physiological assessment

\section{СПОРЕДБЕНА ФИЗИОЛОШКА ПРОЦЕНА НА КРАП (CYPRINUS CARPIO) И КАРАС (CARASSIUS CARASSIUS) ВРЗ ОСНОВА НА ЕЛЕКТРОЛИТСКИ И ХЕМАТОЛОШКИ АНАЛИЗИ}

\begin{abstract}
Студиите кои се засновани на биохемиски и хематолошки параметри се особено важни при следење на здравјето и откривањето на патолошки состојби кај рибите. Оваа истражување ги опфаќа вредностите на серумските електролити и хематолошките параметри кај карасот $(n=15)$ и крапот $(n=13)$. Добиени се значително различни вредности на концентрациите на $\mathrm{K}+\mathrm{Cl}^{-}$и $\mathrm{Ca}^{2+}$. Во серумот на крапот утврдени се значително повисоки концентрации на $\mathrm{K}+$ и $\mathrm{Cl}^{-}$и ниски концентрации на $\mathrm{Ca}^{2+}$ во споредба со карасот. Хематолошките параметри се разликуваат кај овие два вида. Во крвта на крапот, значително се пониски вредностите на PCV, концентрацијата на хемоглобин, RBC и MCV и видно повисоки MCHC и WBC, во споредба со карасот. Ова прелиминарно истражување е важно при одредување на референтни граници на биохемиските и хематолошките параметри кај ципринидните видови риби.
\end{abstract}

Клучни зборови: крап; карас; електролити; хематолошки параметри; физиолошка процена

\section{INTRODUCTION}

Hematological parameters of fish are an indicator of physiological response on environmental stimuli. Ambiental changes have impact on blood cell number, morphology and distribution (Srivastava \& Choudhary, 2010). Analyses of hematological and biochemical parameters in blood are good indicators of environmental and anthropogenic im- pact; also they are biological indicators of fish health status (Çelik, 2004).

Although their classification has not been well defined due to their great variability, a growing belief has appeared in ichthyology, however controversial, that Carassius gibelio (Bloch, 1882) and Carassius carassius (Linnaeus, 1758) have the status of separate species (Jiang et al., 2013). Values of hematological parameters oscilate under dif- 
ferent impacts of external environment. Variations in the blood count could be the result of internal physiological changes and diversity of ecological factors.

The values of biochemical parameters in serum of crucian carp differ in recent literature. Common carp can survive low oxygen concentration $(0.3-0.5 \mathrm{mg} / \mathrm{l})$ as well as high oxigen saturation. Temperature variations affect the glucose, urea, uric acid and protein levels in serum of common carp (Yan et al., 2012). Significant increase in blood glucose level was detected after thermal stress exposure of the common carp, while significant fluctuations of this parameter were not observed in crucian carp (Suljević \& Mitrašinović, 2009). Fish generally have lower blood volume than other vertebrates. Fish, members of genus Carassius (Cypriniformes: Cyprinidae), are more widely used as fish experimental model in various studies (Tsangaris et al., 2011; Falfushynska, et al., 2012; Kreitsberg et al., 2013; Lu et al., 2013). The most research data about biochemical parameters are obtained in Carassius auratus (Xuezhen et al., 2007; Zhengxin et al., 2016). Obtained concentration of serum calcium and glucose showed high individual variations in cyprinids, while in other biochemical parameters statistical significance has not been established (Suljević et al., 2015).

The fish blood is very rich in leukocytes, which are divided into granulocytes (usually fish blood contain more than three types of granulocytes) and agranulocytes. Pseudoeosinophils as specific fish granulocytes are known as heterophils in literature. Because fish do not have the bone marrow and lymph nodes, hematopoesis occurs in other organs. The main hematopoietic organs of fish are kidney, spleen and thymus. Additionally, hematopoesis may occur in the gills, the wall of the small intestine and heart. Part of the kidney named pronephros also has a very important role in hematopoiesis because it is the main site where erythropoiesis, granulopoiesis and lymphopoiesis occur. Reticuloendothelial tissue form the stroma where blast cells take place and this tissue composition is similar to the bone marrow in higher vertebrates (Samali et al., 1999). Blood cell differentiation in fish is the subject of the debate because there is no uniform classification or reference interval for both taxonomic ranks, family and genus.

The aim of this study was to determine physiological advantages and disadvantages in two cyprinid species based on comparative analysis of electrolyte concentration and hematological parameters.

\section{MATERIALS AND METHODS}

\section{Sampling and experimental design}

In this research we analysed biochemical and hematological parameters in two species: Cyprinus carpio (Teleostei: Cyprinidae) from Jablanica lake and Carassius carassius (Teleostei: Cyprinidae) from Bardača lake. Jablanica lake is an artificial lake and has an area of $13 \mathrm{~km}^{2}\left(43^{\circ} 41^{\prime} \mathrm{N} 17^{\circ} 51^{\prime} \mathrm{E}\right)$. Bardača lake near Srbac town is a natural reservoir with an area of $35 \mathrm{~km}^{2}\left(45^{\circ} 4^{\prime}-45^{\circ} 8^{\prime} \mathrm{N}, 17^{\circ} 24^{\prime}-\right.$ $\left.17^{\circ} 30^{\prime} \mathrm{E}\right)$. Fishnets were used for fish sampling. The fish were collected during the winter period (in January). Total number of common carp specimens was 13 and total number of crucian carp specimens was 15 . After catching, fish were placed in a 1001 container with water, which was permanently enriched by oxygen by aerator (CHAMPIONCX-0098) and all fish survived transport.

The adaptation of fish took 20 days (Laboratory of Physiology, Faculty of Science, Sarajevo, Bosnia and Herzegovina) with daily monitoring of water oxygen by Winkler method (Vanselow, 1940), ammonia by Nessler method (Carpenter, 1965). During the adaptation period, the fish were placed in two separate aquariums with the $200 \mathrm{~L}$ volume. Temperature of water was constantly adjusted at $10^{\circ} \mathrm{C}$. Fish were fed with Eco FeedEx C 48/10 (Eco Feed Ltd, Serbia).

\section{Blood sampling and analysis}

The puncture was performed with the sterile needles of $1.0-1.2 \mathrm{~mm}$ (Medoject, Slovak Republic). The collected blood was centrifuged at 3000 rpm for 10 minutes by using Heraeus Sepatech Biofuge model 1217 (Heraeus, Germany) and blood serum was separated for electrolyte analysis. The electrolyte concentration was determined by atomic emission spectroscopy by using Vitros DT 60 (Knauer, Germany).

Hematological parameters included the number of erythrocytes (RBC), hemoglobin concentration $(\mathrm{Hb})$, packed cell volume (PCV), mean corpuscular volume (MCV), mean corpuscular hemoglobin $(\mathrm{MCH})$, mean corpuscular hemoglobin concentration (MCHC) and the number of leukocytes (WBC). The number of erythrocytes and leukocytes were determined in a Neubauer chamber (hemocytometer) according to the method of Kekić 
\& Ivanc (1982). Hb was estimated by Drabkin hemoglobin cyanide method (Blaxhall and Daisly, 1973), and PCV was determined by microhematocritic centrifuges (Hettich Haematokrit 24 zentrifugen, Germany). Hematological values (MCV, $\mathrm{MCH}$ and MCHC) were calculated based on the values of $\mathrm{PCV}$, number of erythrocytes and $\mathrm{Hb}$ concentration. Euthanasia and all procedures with animals were conducted in accordance to the Directive 2010/63/EU of the the European Parliament and of the the Council of 22 September 2010 on the protection of animals used for scientific purposes.

\section{Statistics}

Data are presented as arithmetic mean \pm 1 SD with minimum and maximum values or range. The Shapiro-Wilk test was used to estimate the normality of data distribution. Student's t-test was used to asses the differences between the groups. Statistical analysis were performed by SPSS (Version 20.0, SPSS, Inc., Chicago, IL, USA).

\section{RESULTS}

\section{Morphometric features}

Figure 1 presents morphometric characteristics of common carp. The average value of weight in common carp was $10.88 \pm 1.15 \mathrm{~g}$. Distribution of weight frequency showed that large number of specimens (4) had average weight of approxi- matelly 10 g. Total body length was $13.06 \pm 1.29$ $\mathrm{cm}$, while large number of specimens (5) had a length of $13 \mathrm{~cm}$.

Figure 2 presents morphometric characteristics of crucian carp. Average weight value was $69.26 \pm 7.30$ g. Distribution of weight frequency showed that most of the specimens (5) had average weight value of aproximatelly $75 \mathrm{~g}$. Total length was $16.44 \pm 0.943 \mathrm{~cm}$, while the frequency distribution was homogeneous in most specimens.

\section{Electrolyte analysis}

Table 1. presents values of electrolyte concentrations in Cyprinus carpio and Carassius carassius. In serum of common carp were obtained significantly higher $\mathrm{Na}^{+}, \mathrm{K}^{+} \mathrm{i} \mathrm{Cl}^{-}$and lower $\mathrm{Ca}^{2+}$ concentrations than in the serum of crucian carp. Considerably different values of $\mathrm{K}^{+}, \mathrm{Cl}^{-} \mathrm{i} \mathrm{Ca}^{2+}$ $(\mathrm{p}<0.05)$ were detected, while the Shapiro-Wilk test showed notable difference in comparison with standard $\mathrm{K}^{+} \mathrm{i} \mathrm{Ca}^{2+}$ distribution $(\mathrm{p}<0.05)$.

\section{Hematological analysis}

Hematological values such as erythrocyte count (RBC), hemoglobin concentration $(\mathrm{Hb})$, packed cell volume (PCV), mean corpuscular volume (MCV), mean corpuscular hemoglobin $(\mathrm{MCH})$, mean corpuscular hemoglobin concentration (MCHC) and leukocyte count (WBC) in the blood of common carp and the crucian carp are shown in Table 2.
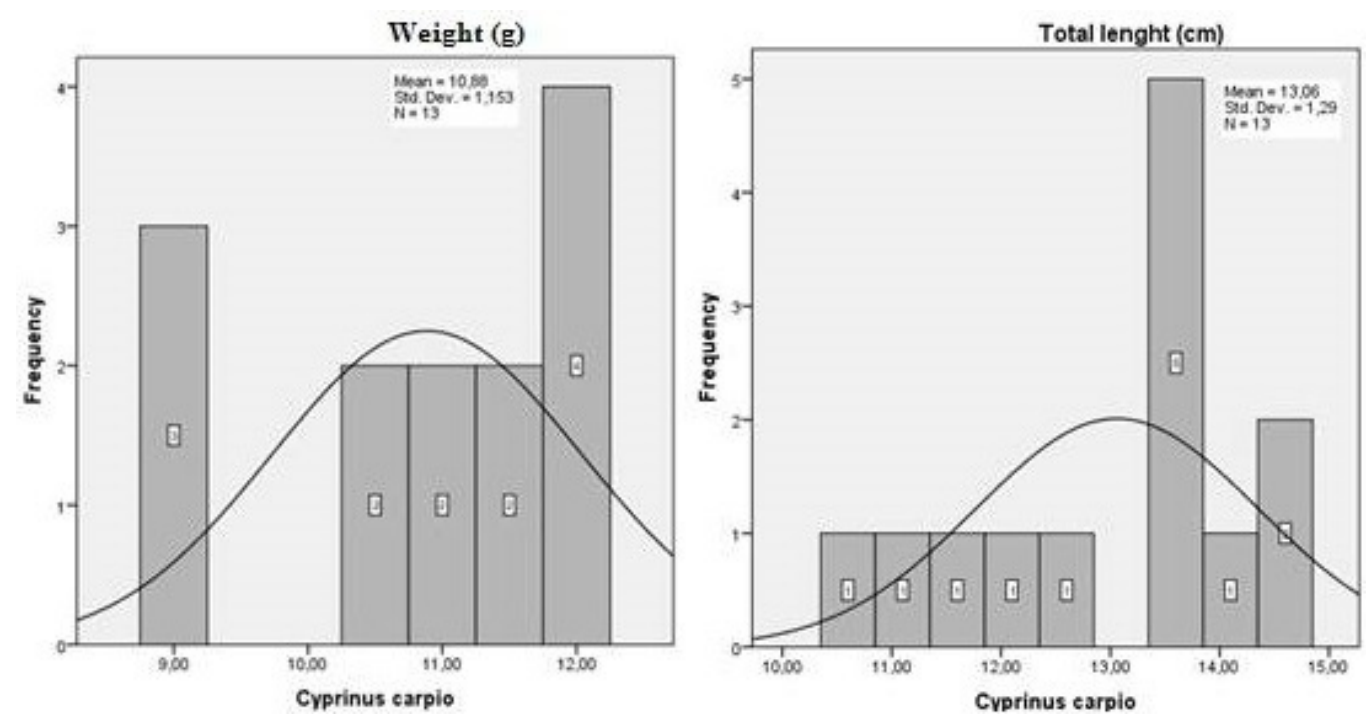

Fig. 1. Average length $(\mathrm{cm})$ and weight $(\mathrm{g})$ of Cyprinus carpio 

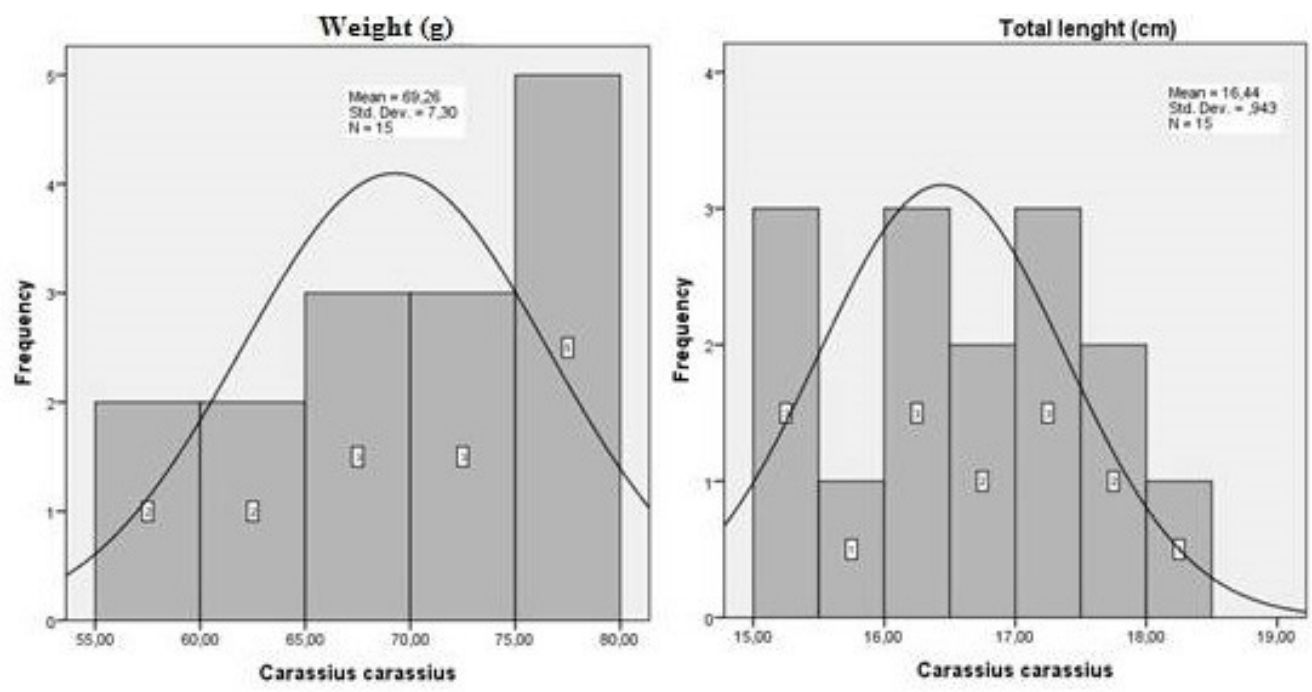

Fig. 2. Average length (cm) and weight (g) of Carassius carassius

Table 1

Comparative values of electrolytes in Cyprinus carpio and Carassius carassius serum (mmol/l)

\begin{tabular}{lcccccc}
\hline \hline \multirow{2}{*}{ Parameter } & \multicolumn{2}{c}{ Cyprinus carpio } & Carassius carassius & t-test & Shapiro W \\
\cline { 2 - 7 } & Mean $\pm \mathrm{SD}$ & Range & Mean $\pm \mathrm{SD}$ & Range & \multicolumn{2}{c}{ p-values } \\
\hline $\mathrm{Na}^{+}$ & $136.5 \pm 4.52$ & $127-142$ & $135.20 \pm 4.35$ & $126-142$ & 0.09 & 0.240 \\
$\mathrm{~K}^{+}$ & $1.84 \pm 0.55$ & $1.30-2.90$ & $1.14 \pm 4.31$ & $0.60-2.60$ & 0.00 & 0.00 \\
$\mathrm{Cl}^{-}$ & $106.31 \pm 4.84$ & $99-113$ & $101.93 \pm 0.54$ & $93-108$ & 0.00 & 0.974 \\
$\mathrm{Ca}^{2+}$ & $1.26 \pm 0.26$ & $0.95-1.78$ & $2.59 \pm 0.45$ & $1.64-3.18$ & 0.00 & 0.032 \\
\hline \hline
\end{tabular}

Table 2

Comparative values of hematological parameters in Cyprinus carpio and Carassius carassius blood

\begin{tabular}{|c|c|c|c|c|c|c|}
\hline \multirow{3}{*}{$\begin{array}{l}\text { Parameter } \\
\text { PCV }\end{array}$} & \multicolumn{2}{|c|}{ Cyprinus carpio } & \multicolumn{2}{|c|}{ Carassius carassius } & t-test & Shapiro W \\
\hline & \multirow{2}{*}{$\begin{array}{l}\text { Mean } \pm \text { SD } \\
0.25 \pm 0.04\end{array}$} & \multirow{2}{*}{$\begin{array}{c}\text { Range } \\
0.19-0.31\end{array}$} & \multirow{2}{*}{$\begin{array}{l}\text { Mean } \pm \text { SD } \\
0.31 \pm 0.09\end{array}$} & \multirow{2}{*}{$\begin{array}{c}\text { Range } \\
0.25-0.58\end{array}$} & \multicolumn{2}{|c|}{ p-values } \\
\hline & & & & & 0.00 & 0.592 \\
\hline $\mathrm{Hb}(\mathrm{g} / \mathrm{l})$ & $73.215 \pm 9.19$ & $56.8-87.50$ & $79.50 \pm 9.81$ & $60.42-97.66$ & 0.293 & 0.802 \\
\hline $\mathrm{RBC} \times 10^{12}$ & $1.16 \pm 0.07$ & $1.04-1.25$ & $1.27 \pm 0.16$ & $1.01-1.51$ & 0.00 & 0.000 \\
\hline MCV (fL) & $219.94 \pm 33.47$ & $163.6-269.6$ & $242.54 \pm 53.28$ & $165.5-402$ & 0.001 & 0.587 \\
\hline $\mathrm{MCH}(\mathrm{pg})$ & $63.36 \pm 9.28$ & $50.27-79.01$ & $63.26 \pm 11.18$ & $40.01-84.90$ & 0.329 & 0.094 \\
\hline $\operatorname{MCHC}(\mathrm{g} / \mathrm{dl})$ & $290.5 \pm 35.05$ & $224.4-335.12$ & $267.79 \pm 53.99$ & $136.23-377.07$ & 0.00 & 0.819 \\
\hline $\mathrm{WBC} \times 10^{6}$ & $4.50 \pm 0.42$ & $4.00-5.30$ & $3.63 \pm 0.90$ & $2.50-4.75$ & 0.00 & 0.011 \\
\hline
\end{tabular}

The common carp had higher values of $\mathrm{MCHC}$ and $\mathrm{WBC}(\mathrm{p}<0.05)$. There were no notable differences in the average values of $\mathrm{MCH}$ ( $>0.05)$. The crucian carp had considerably higher values of: PCV, Hb, RBC and MCV ( $\mathrm{p}<0.05)$. We did not establish significant differences in hemoglobin and $\mathrm{MCH}(\mathrm{p}>0.05)$, while other parameters are notably different in both species $(\mathrm{p}<0.05)$. RBC and WBC $(\mathrm{p}<0.05)$ considerably deviate from the standard values. 


\section{DISCUSSION}

There is a growing interest in the study of hematological parameters and structural features of fish blood cells. They are important for aquacultural purposes and comparative physiology. Hematological and biochemical values are important in the evaluation of physiological condition of fish. In order to use blood parameters as biomarkers, it is important to know their standard values and reference interval. This research is particularly valuable for rare and endangered species of fish as shown also in (Dekić et al., 2014). Recent studies have aquired very few hematological data, especially in biochemical values. There are no available data for blood values of these species, that fact makes this research very valuable. Hematological and biochemical values can be compared to other cyprinid species. Although they belong to the same family, the common carp and crucian carp had different concentration of serum minerals. $\mathrm{Na}^{+}$and $\mathrm{Cl}^{-}$are higher in comparison to the tench (Suljević et al., 2015), $\mathrm{K}^{+}$concentration in tench was higher in relation to the crucian carp and lower in relation to common carp. The common carp had a lower serum $\mathrm{Ca}^{2+}$ than tench and the crucian carp. $\mathrm{K}^{+}$values were considerably higher than those of the rainbow trout while the values of $\mathrm{Na}^{+}$and $\mathrm{Cl}^{-}$were lower (Hasković et al., 2011).

Age, habitat, season and nutritional factors have an impact on changes in blood parameters. Generally, it is not possible to establish standard values for fish. Reference interval is hard to determine within the family. Therefore, every species needs to be individually analysed. Normality of blood values distribution is significant indicator of physiological state of analysed fish (Sokal \& Rohlf, 1995). RBC values were lower than in Delminichthys ghetaldii (Dekić et al., 2014) and Telestes metohiensis from the Pribitul stream (Dekić et al., 2011). Some other cyprindis had higher RBC, like Aulopyge hugeli, Leuciscus tursky, Chondrostoma phoxinus (Vuković \& ZnidaršićKrižek, 1969), Leuciscus cephalus (Mitrašinović \& Suljević, 2009). RBC values may vary within the same species, under certain physiological limitations. This leads to the different referential data (Dekić, 2010). According to Bogut et al. (2006) RBC values for common carp vary between 1.8$2.2 \times 10^{12} / 1$. These values are considerably higher than the values obtained by our research. Values of PCV in common carp were considerably lower in comparison to the previous research with the same species (Groff \& Zinkl, 1999) and were more simi- lar to the values obtained for crucian carp. According to Hrubec et al. (2000) obtained PCV values and the $\mathrm{Hb}$ concentration are in the referential interval while the RBC number was very low.

The crucian carp has higher $\mathrm{RBC}$ and $\mathrm{Hb}$ concentration. This explains why crucian carp is physiologicaly stronger than the common carp. Crucian carp had higher RBC, which leads to the higher levels of other hematological values. These findings are similar in other research, like those of Leuciscus cephalus (Mitrašinović \& Suljević, 2009).

Some studies include thrombocytes (Hrubec et al., 2000; Hrubec et al., 2001) in the WBC. Our research indicates that the common carp had higher WBC in comparison to crucian carp. These numbers deviate from the earlier findings (Hrubec et al., 2001) that showed higher WBC number in crucian carp. Hrubec et al. (2000) presented reference WBC values in the interval of 2.15 to 15.47 $\times 10^{12} / 1$, while our research showed higher WBC in both observed species in comparison to other Teleostei (Hrubec et al, 2001; Or̈un \& Erdemli, 2002; Kori-Siakpere et al., 2005; Rey V́azquez \& Guerrero, 2007). Higher WBC number of the common carp may suggest that its immune system is more sensitive to the environmental stress, which makes crucian carp very adaptable to extreme environmental conditions.

The findings in our research contribute to the knowledge about the biochemical and hematological parameters in Cyprinus carpio and Carassius carassius. These findings may be valuable for the overall health assessment of these and other cyprinids. Hematological evaluation is significant in the early detection of health problems. Hematological values of Carassius carassius indicate more efficient energy metabolism and better adaptation abilities than observed for Cyprinus carpio. Hematological characteristics of Carassius carassius justify its survival abilities in extreme environmental conditions.

Conflict of interest statement: There is no any conflict of interest!

\section{REFERENCES}

[1] Blaxhall, P. C., Daisly, K. W.: Routine hematological methods for use with fish blood. Journal of Fish biology, 5, 771-781 (1973).

[2] Bogut, I., Novoselić, D. \& Pavlićević, J. 2006. Biologija riba. Sveučilište J.J. Strossmayera u Osijeku, Sveučilište u Mostaru, pp 88-95. 
[3] Carpenter, J. H.: Technique for the Winkler oxygen method. ASLO, 10, 141-143 (1965).

[4] Çelik, E. S.: Blood chemistry (electrolytes, lipoproteins and enzymes) values of Black Scorpion Fish (Scorpaena porcus Linneaus, 1758) in the Dardanelles, Turkey. Journal of Biological Sciences, 4 (6), 716-719 (2004).

[5] Dekić, R.: Cirkanualna istraživanja hematološkog statusa Barbus peloponnesius u funkciji staništa. Doktorska disertacija. Univerzitet u Banjoj Luci, 2010.

[6] Dekić, R., Ivanc, A., Lolić, S., Bošković, J., Obradović, S. \& Ćetković, D.: The recent state of distribution of endemic fish species in Eastern Herzegovina,. V International Conference "Aquaculture and Fishery" Faculty of Agriculture, Belgrade-Zemun, Serbia, Conference proceedings, 195-199, 2011.

[7] Dekić, R., Ivanc, A., Erić, Ž., Gnjato, R., Trbić, G., Lolić, S., Manojlović, M. \& Janić, N.: Hematological characteristics of Delminichthys ghetaldii (Steindachner 1882) in habiting the Karst region of Eastern Herzegovina. Archive of Biological Science Belgrade, 66 (4),1423-1430 (2014).

[8] Falfushynska, H. I., Gnatyshyna, L. L., Stoliar, O. B.: Population-related molecular responses on the effect of pesticides in Carassius auratus gibelio. Comparative Biochemistry and Physiology, 155, 396-406 (2012).

[9] Groff, J. M., Zinkl, J. G.: Hematology and clinical chemistry of Cyprinid fish. Common carp and goldfish. Veterinary Clinicas of North America: Exotic Animal Practice, 2 (3), 741-746 (1999).

[10] Hasković, E., Džajić, A., Suljević, D.: Biochemical status of blood serum of rainbow trout Oncorhynchus mykiss (Walbaum, 1792) under different keeping and feeding conditions. Veterinaria Sarajevo, 60 (3-4), 141-152 (2011).

[11] Hrubec, T. C., Cardinale, J. L., Smith, S. A.: Hematology and plasma chemistry reference intervals for cultured tilapia (Oreochromis hybrid). Veterinary Clinical Pathology, 29 (1), 7-12 (2000).

[12] Hrubec, T. C., Smith, S. A., Robertson, J. L.: Age related in haematology and chemistry values of hybrid striped bass chrysops Morone saxatilis. Veterinary Clinical Pathology, 30 (1), 8-15 (2001).

[13] Jiang, F. F., Wang, Z. W., Zhou, L., Jiang, L., Zhang, X. J., Apalikova, O. V., Brykov, V. A., Gui, J. F.: High male incidence and evolutionary implications of triploid form in northeast Asia Carassius auratus complex. Molecular Phylogenetics and Evolution, 66, 350-359 (2013).

[14] Kekić, H. \& Ivanc, A. 1982. A new direct method for counting fish blood cells. Ichtyologia, 14(1):55-58.

[15] Kori-Siakpere, O., Ake, J. E. G., Idoge, E.: Haematological characteristics of the African snakehead, Parachacnna obscura. African Journal of Biotechnology, 4 (6), 527530 (2005).

[16] Kreitsberg, R., Baršienė, J., Freiberg, R., Andreikènaitė, L., Tammaru, T., Rumvolt, K., Tuvikene, A. L.: Biomarkers of effects of hypoxia and oil-shale contaminated sediments in laboratory-exposed gibel carp (Carassius auratus gibelio). Ecotoxicology and Environmental Safety, 98, 227-235 (2013).
[17] Lu, G. H., Qi, P. D., Chen, W.: Integrated biomarker responses of Carassius auratus exposed to BDE-47, BDE-99 and their mixtures. International Journal of Environmental Research, 7 (3), 807- 816 (2013).

[18] Mitrašinović, M., Suljević, D.: Hematological status of chub fish Leuciscus chephalus (Linnaeus, 1758.) from Krupica and Željeznica rivers. Veterinaria Sarajevo, 58 (1-2), 63-76 (2009).

[19] Ö̈un, I., Erdemli, A. U.: A study on blood parameters of Capoeta trutta (Heckel, 1843). Jornal of Biological Sciencis, 2 (8), 508-511 (2002).

[20] Rey V́azquez, G., Guerrero, G. A.: Characterization of blood cells and hematological parameters in Cichlasoma dimerus (Teleostei, Perciformes). Tissue and Cell, 39, 151-160 (2007).

[21] Samali, A., Zhivotovsky, B., Jones, D., Nagata, S., Orrenius, S.: Apoptosis: cell death defined by caspase activation. Cell Death and Differentiation, 6 (6), 495-496 (1999).

[22] Sokal, R. R., Rohlf, F. J.: Biometry: the principles and practice of statistics in biological research. Third edition. W. H. Freeman and Company, San Francisco, 1995. pp 859.

[23] Srivastava, S., Choudhary, S. K.: Effect of artificial photoperiod on the blood cell indices of the catfish, Clarias batrachus. Choudhary Journal of Stress Physiology \& Biochemistry, 68 (1), 22-32 (2010).

[24] Suljević, D., Mitrašinović, M.: Effects of thermal stress on glucose level in serum of carp and crucian carp. Veterinaria Sarajevo, 58 (3-4), 201-209 (2009).

[25] Suljevíć, D., Islamagíc, E., Fočak, M.: The effects of high temperature level on electrolytes and glucose concentration in tench (Tinca tinca Linnaeus, 1758) serum. Veterinaria Sarajevo, 64 (2), 60-64 (2015).

[26] Tsangaris, C., Vergolyas, M., Fountoulaki, E., Goncharuk, V. V.: Genotoxicity and oxidative stress biomarkers in Carassius gibelio as endpoints for toxicity testing of Ukrainian polluted river waters. Ecotoxicology and Environmental Safety, 74 (8), 2240-2244 (2011).

[27] Vanselow, A. P.: Preparation of Nessler's reagent. Industrial \& Engineering Chemistry Analytical, 12, 516-517 (1940).

[28] Vuković, T., Žnidaršić-Krzyk, S.: Broj eritrocita, broj leukocita i koncentracija hemoglobina u nekih ciprinidnih vrsta riba. Croatian Journal of Fisheries, 24 (1), 10-11 (1969).

[29] Xuezhen, Z., Ping, X., Dapeng, L., Zechao, S.: Hematological and plasma biochemical responses of crucian carp (Carassius auratus) to intraperitoneal injection of extracted microcystins with the possible mechanisms of anemia. Toxicon, 49 (8), 1150-1157 (2007).

[30] Yan, G. J., He, X. K., Cao, Z. D., Fu, S. J.: The trade-off between steady and unsteady swimming performance in six cyprinids at two temperatures. Journal of Thermal Biology, 37, 424-431 (2012).

[31] Zhengxin, X., Guanghua, L., Sheng L., Yang, N., Binni, M., Jianchao, L.: Behavioral and biochemical responses in freshwater fish Carassius auratus exposed to sertraline. Chemosphere, 135, 146-155 (2016). 